\title{
Pelatihan Penggunaan KIT IPA Bagi Guru dan Siswa SMP N 1 Sakra Lotim
}

\author{
Satutik Rahayu $^{1 *}$, Ahmad Harjono ${ }^{1}$, I Wayan Gunada ${ }^{1}$ \\ ${ }^{I}$ Program Studi Pendidikan Fisika FKIP Universitas Mataram, Mataram, Nusa Tenggara Barat, Indonesia
}

*Corresponding Author: Satutik Rahayu, Universitas Mataram, Mataram, Indonesia; Email: satuti4977@yahoo.co.id

\section{Pendahuluan}

Peraturan tentang pembelajaran Ilmu Pengetahuan Alam secara terpadu sudah diatur dalam Permendikbud No. 22 Tahun 2006 yang menjelaskan bahwa substansi mata pelajaran IPA pada SMP/MTs merupakan "IPA Terpadu". Pembelajaran IPA diintegrasikan melalui konten biologi, fisika, kimia. Percobaan atau praktikum merupakan bagian terpenting dari pembelajaran IPA hal ini dikarenakan IPA adalah ilmu alam yang didasarkan pada penemuan berdasarkan gejalagejala fisis pada kehidupan sehari-hari. Pada mata pelajaran IPA, konsep dan sub-konsep dipelajari melalui penelitian sederhana, percobaan dan sejumlah kegiatan praktis dengan fokus pada pengembangan keterampilan proses. Hakikat dari ilmu sains adalah proses penemuan (inquiry). Idealnya, setiap topik dari pembelajaran IPA sebaiknya diajarkan melalui peragaan kepada siswa, dalam bentuk percobaan atau demonstrasi yang dilakukan di Laboratorium.

Mengajarkan mata pelajaran tidak cukup hanya dengan menggunakan kapur dan papan tulis saja. Sekarang ini tuntutan pembelajaran tidak hanya memberikan sejumlah fakta, yang makin lama jumlahnya makin banyak yang harus dihafalkan oleh siswa, tetapi siswa juga harus dapat menjelaskan mengapa fakta itu ada, bagaimana fakta itu terjadi, dan di mana fakta itu dapat terjadi. Agar siswa dapat memahami seluruh tuntutan pembelajaran itu, tidak cukup dengan hanya memberikan ceramah kepada siswa.

Agar dalam proses pembelajaran sesuai dengan tujuan pembelajaran IPA di SMP, maka diperlukan suatu sarana peralatan laboratorium IPA (Fisika) untuk melakukan percobaan Fisika. Pemerintah telah memberikan peralatan laboratorium berupa Kit IPA (Fisika). Kit IPA (Fisika) adalah peralatan laboratorium/praktikum Fisika yang dikemas dalam bentuk modular kit. Modular Kit dengan sistim pengepakan yang lebih rapi dan praktis akan membantu sekolah memiliki peralatan yang baku, bersifat serba guna dan berdaya guna tinggi serta tahan lama. Secara keseluruhan jenis-jenis percobaan yang dapat dilaksanakan dengan percobaan kit ini telah disesuaikan dengan ketentuan di dalam Kurikulum yang berlaku.

Berdasarkan hasil wawancara dengan beberapa guru IPA ditemukan beberapa permasalahan diantaranya dalam proses pembelajaran IPA terutama pada materi fisika guru jarang melakukan pembelajaran dengan menggunakan metode eksperimen. Akar dari permasalahannya adalah para guru IPA takut 
melakukan percobaan yang berhubungan dengan listrik dan guru-guru juga jarang melakukan percobaan-percobaan-percobaan dengan menggunakan KIT. Alat peraga merupakan salah satu komponen pembelajaran yang mempunyai peranan penting dalam proses belajar mengajar. Hartati (2010) mengungkapkan bahwa untuk penunjang terselenggaranya proses pembelajaran yang menyenangkan perlu disediakan alat peraga yang memadai. Alat peraga dapat memperjelas bahan pengajaran yang diberikan guru kepada siswa sehingga siswa lebih mudah memahami materi atau soal yang disajikan guru. Alat peraga juga menarik perhatian siswa dan dapat menumbuhkan minat untuk mengikuti pembelajaran IPA (Prasetyarini, 2013). Pemanfaatan alat peraga merupakan bagian yang harus mendapat perhatian pihak sekolah dalam setiap kegiatan pembelajaran. Banyak sekolah yang memiliki alat peraga pendidikan seperti KIT IPA yang telah dikemas dengan praktis namun belum digunakan secara optimal. Pelatihan ini ditujukan bagi para guru, laboran, teknisi, dan peserta yang berminat untuk mempelajari tata cara penggunaan, perawatan dan pemeliharaan alat peraga agar penggunaan alat peraga menjadi lebih efektif, kreatif, dan efisien, sedangkan untuk pengenalan alat-alat ditujukan pada siswa.

\section{Metode Pelaksanaan}

Kegiatan ini dilakukan di SMP N 1 Sakra. Berikut Dokumentasi para peserta yang sedang mengikuti pelatihan.

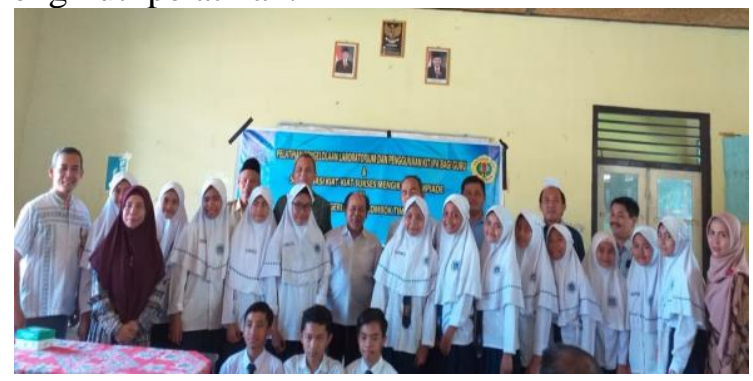

Gambar 1. Peserta Kegiatan Pengabdian Kepada Masyarakat

Secara umum metode pelaksanaan yang digunakan dalam kegiatan pengabdian kepada masyarakat ini menggunakan metode ceramah, tanya jawab dan diskusi.

Agar pembelajaran IPA dapat berlangsung sesuai harapan, maka diperlukan beberapa hal, antara lain kemampuan guru dan sarana pendukung untuk penunjang pembelajaran. Sanjaya (2010), Sarana adalah segala sesuatu yang mendukung secara langsung terhadap kelancaran proses pembelajaran. Laboratorium adalah tempat sekelompok orang yang melakukan berbagai macam kegiatan penelitian (riset), pengamatan, pelatihan dan pengujan ilmiah sebagai pendekatan antara teori dan praktik dari berrbagai macam disiplin ilmu. Secara fisik laboratorium juga dapat merujuk kepada suatu ruangan tertutup, kamar atau ruangan terbuka. Richard(2013) menyatakan bahwa laboratorium IPA merupakan sarana pendukung agar proses pembelajaran dapat berjalan efektif. KIT IPA berupa seperangkat alat/komponen yang ditempatkan dalam suatu tempat tertentu yang berfungsi sebagai alat peraga IPA.

\section{Hasil dan Pembahasan}

Untuk meningkatkan pembelajaran dengan memanfaatkan laboratorium sebagai sarana pembelajaran IPA maka Tim pengabdian kepada masyarakat melaksanakan pelatihan kepada guru dan siswa SMP N 1 Praya. Adapun kegiatan ini dilaksanakan selama satu hari dengan rincian kegiatan sebagai berikut :

1. Kegiatan pertama adalah memberikan pelatihan kepada guru guru tentang pentingnya mengelola laboratorium sebagai sarana pembelajaran. Emda (2014) menyatakan bahwa laboratorium merupakan wadah untuk membuktikan sesuatu yang harus dilakukan melalui suatu percobaan. Pada sesi ini tim pengabdian memberikan pelatihan bagaimana mengelola laboratorium yang baik, bagaimana merawat alat-alat laboratorium setelah digunakan.

2. Kegiatan kedua adalah memberikan pelatihan kepada siswa-siswa tentang penggunaan KIT IPA. Untuk dapat memiliki keterampilan menggunakan alat dan bahan, dengan sendirinya peserta didik harus menggunakan secara langsung alat dan bahan agar dapat memperoleh pengalaman langsung. Selain itu, peserta didik harus mengetahui mengapa dan bagaimana cara menggunakan alat dan bahan. Pada sesi ini tim pengabdian mengenalkan macammacam alat yang terdapat di dalam KIT beserta kegunaannya, cara merakit alat sampai dengan bagaiman pengambilan data suatu percobaan. Anak-anak antusis mengikuti kegiatan pelatihan ini. 


\section{a. Faktor pendorong}

Peserta pelatihan adalah guru-guru dan siswa SMP N 1 Sakra. Melalui kegiatan pelatihan ini diharapkan guru dan siswa dapat memanfaatkan alat-alat KIT IPA sebagai media pembelajaran IPA. Kegiatan ini bagus dilaksanakan untuk memperbaiki proses pembelajaran mengingat hakikat IPA adalah produk, sikap dan proses..

\section{b. Faktor Penghambat}

Keinginan untuk melatih guru dan siswa dalam penggunaan semua KIT IPA (Fisika) belum terlaksana secara maksimal karena terbatasnya waktu dan biaya untuk pengabdian. Para peserta berharap bisa dilakukan pelatihan lebih lama terkait bagimana melakukan percobaan untuk semua judul yang ada di dalam box KIT IPA.

\section{Kesimpulan}

Kegiatan Pelatihan ini dapat menambah wawasan dan pengetahuan guru-guru dan siswa semoga melalui pelatihan ini guru lebih senang mengajar IPA dengan memanfaatkan KIT IPA. Bagi siswa diharapkan menjadi lebih menyenangi pembelajaran IPA khususnya fisika.

\section{Saran}

Kegiatan pelatihan ini sebaiknya dilaksanakan dengan melalui workshop tidak Cuma sehari dilaksanakan agar semua materi yang terdapat di dalam KIT dapat diperagakan.

\section{Ucapan Terimakasih}

Penulis mengucapkan terimakasih kepada DRPM, Kemenristekdikti, Rektor Universitas Mataram, dan Ketua LPPM Universitas Mataram yang telah memfasilitasi pembiayaan kegiatan pengabdian kepada masyarakat dengan dana DIPA PNBP melalui Surat Perjanjian Nomor: 2413/UN.18/LPPM/2019. Penulis juga mengucapkan terimakasih kepada Guru-guru SMP N 1 Sakra dan para siswa sebagai peserta pelatihan dan pihak lain yang telah memberikan masukan dalam upaya penyempurnaan tulisan ini.

\section{Daftar Pustaka}

Hartati, B. 2010. Pengembangan Alat Peraga Gaya Gesek Untuk Meningkatkan Keterampilan Berpikir Kritis Siswa SMA. Jurnal Pendidikan Fisika Indonesia, vol 6 : 128132.

Emda, A. 2014. Laboratorium sebagai sarana pembelajaran Kimia dalam meningkatkan pengetahuan dan keterampilan kerja Ilmiah. Lantanida Journal, Vol. 2 No. 2, 2014 h.218-229

Prasetyarini, A., Desy, S. F., \& Akhdinirwanto, W. 2013. Pemanfaatan Alat Peraga IPA untuk Peningkatan Pemahaman Konsep Fisika pada Siswa SMP Negeri 1 Bulupesantren Kebumen Tahun Pelajaran 2012/2013. Radiasi, vol 2 (1) : 7-10

Richard,D. 2013. Tips mengelola lab sekolah, Jogyakarta : Diva Press.

Sanjaya, W. 2010. Kurikulum dan Pembelajaran, Teori dan Praktek KTSP. Jakarta: Kencana 